\title{
Assessment of the nutritional status of grassland: nitrogen nutrition index
}

\author{
Avaliação do estado nutricional da pastagem: \\ índice nutricional de nitrogênio
}

\author{
Laércio Ricardo Sartor ${ }^{*}$; Tangriani Simioni Assmann²; André Brugnara Soares²; \\ Paulo Fernando Adami ${ }^{3}$; Alceu Luis Assmann ${ }^{4}$; Sidney Ortiz ${ }^{5}$
}

\begin{abstract}
The aim of this study was to assess the Nitrogen Nutrition Index (NNI) of an Urochloa plantaginea pasture submitted to different nitrogen (N) levels and forage mass (FM) through dilution curve model. The experimental design was a random block with six treatments in a factorial scheme. The treatments combination consisted of three nitrogen levels $\left(0,200\right.$ and $400 \mathrm{~kg} \mathrm{ha}^{-1}$ of N) and two forage mass (low mass at 2,000 kg ha-1 of DM and high mass at 3,600 $\mathrm{kg} \mathrm{ha}^{-1}$ of DM) in a continuous stocking rate grazing method. Urochloa plantaginea forage production was higher at the nitrogen intermediate level $(200 \mathrm{~kg}$ ha $^{-1}$ of $\mathrm{N}$ ), being $31 \%$ superior than treatment without nitrogen, which showed unsatisfactory nitrogen nutritional index and due to it, limited forage growth. This fact was not observed at the $400 \mathrm{~kg} \mathrm{ha}^{-1}$ of $\mathrm{N}$, where nitrogen luxury consumption occurred showed by the satisfactory levels of this nutrient in the plant tissue. Nitrogen dilution curve allows the diagnosis of the plants nutritional status.
\end{abstract}

Key words: Dilution curve, fertility, forage production, nutritive value, Urochloa plantaginea

\section{Resumo}

O objetivo desse estudo foi avaliar o status de nutrição nitrogenada (INN) da pastagem de Urochloa plantaginea submetida a doses de nitrogênio e intensidades de pastejo, através do modelo de diluição do nitrogênio. $\mathrm{O}$ experimento foi conduzido com objetivo de avaliar a dinâmica do nitrogênio de uma pastagem de Urochloa plantaginea. O delineamento experimental foi o de blocos ao acaso e os tratamentos compostos da combinação de crescentes doses de nitrogênio $\left(0,200\right.$ e $\left.400 \mathrm{~kg} \mathrm{ha}^{-1}\right)$ e duas massas de forragem (massa baixa com $2.000 \mathrm{~kg} \mathrm{ha}^{-1}$ de MS e massa alta $3.600 \mathrm{~kg} \mathrm{ha}^{-1}$ de MS) em pastejo contínuo com taxa de lotação variável, perfazendo seis tratamentos em esquema fatorial. A produção de forragem de $U$. plantaginea foi maior na dose de $200 \mathrm{~kg} \mathrm{ha}^{-1} \mathrm{de} \mathrm{N}, 31 \%$ superior ao tratamento sem nitrogênio, que apresentaram índice nutricional de nitrogênio insatisfatório e, devido a isso, o crescimento da forragem limitado. Este fato não foi observado com $400 \mathrm{~kg} \mathrm{ha}^{-1} \mathrm{de} \mathrm{N}$, onde o consumo de luxo de nitrogênio ocorreu demonstrado pelos níveis satisfatórios desse nutriente no tecido vegetal. O INN possibilita a diagnose da condição nutricional das plantas.

Palavras-chave: Curva de diluição, fertilidade, produção de forragem, valor nutritivo, Urochloa plantaginea

\footnotetext{
${ }^{1}$ Prof. da Universidade Tecnológica Federal do Paraná, UTFPR, Dois Vizinhos, PR, Brasil. E-mail: laerciosartor@utfpr.edu.br

2 Profs. da UTFPR, Pato Branco, PR, Brasil. E-mail: tangriani@utfpr.edu.br; soares@utfpr.edu.br

${ }^{3}$ Prof. do Instituto Federal do Paraná, Palmas, PR, Brasil. E-mail: paulo.adami@ifpr.edu.br

${ }^{4}$ Pesquisador do Instituto Agronômico do Paraná, IAPAR, Pato Branco, PR, Brasil. E-mail: assmann@iapar.br

${ }^{5}$ Discente do Programa de Pós Graduação em Zootecnia, UTFPR, Dois Vizinhos, PR, Brasil. E-mail:ortizsidney@yahoo.com.br

* Author for correspondence
} 


\section{Introduction}

Nutritional status of a plant depends of available minerals besides good climate conditions on the soil. Under satisfactory conditions of climate and rainfall, soil fertility is the determining factor in the forage production and quality (MARTINS; RESTLE; BARRETO, 2000). Furthermore, many authors agree with the statement that among the nutrients, nitrogen is the one that most influences pasture production after water (LEMAIRE; JEUFFROY; GASTAL, 2008).

Nitrogen efficiency use depends of the forage species and the requirement imposed by this species. Urochloa plantaginea is annual specie known as a weed plant of annual crops such as corn and soybean. It has natural reseeding abilities and frequently appears spontaneously in the southern of Brazil from the beginning of spring and early fall (ARAÚJO, 1967).

Nitrogen, in its forms, is mobile in the soil and due to it, is considered a nutrient not conservative in many circumstances (JARVIS, 1999). It is difficult to determine with accuracy its levels and because of this, some authors suggest diagnoses, such as fodder chemical analysis. Lemaire and Salette (1984), showed that nitrogen concentration in grasses growing in non-limiting nitrogen supply can be related to the dry matter accumulation by a simple equation and from that, a mathematical model was developed and can nowadays be used for a wide range of plant species. With this study it is possible to take decisions regarding to the appliance or not of extra levels of nitrogen for maximum dry matter production efficiency, especially in pasture, aiming for a greater period of use.

There are few reports in Brazil concerning the determination of nitrogen nutrition index through this methodology and there is a lack of studies in search of methodologies to facilitate the diagnosis of the nutritional status of plants as a management tool to avoid problems such pastures degradation and low production. Especially because the country has about 177 million hectares of pasture (SILVA; NASCIMENTO JUNIOR, 2006), and it is estimated that more than $50 \%$ of this areas shows some stage of degradation, resulting in bare soil and subsequent erosion.

The low nutritional status frequently observed is a major cause of pasture degradation which is nowadays one of the serious agricultural problems in Brazil. Some studies confirm and validate this method as a effective away to check the nutritional status of various plant species (PLÉNET; LEMAIRE, 2000, SHEEHY et al., 1998; COLNENNE et al., 1998, LEMAIRE; GASTAL, 1997; DURU; LEMAIRE; CRUZ, 1997; PLÉNET; CRUZ, 1997; NEY; DORE; SAGAN, 1997), but unfortunately, few studies report the diagnosis of grazing pastures with tropical species in Brazil.

The aim of this study was to assess the Nitrogen Nutrition Index (NNI) of an Urochloa plantaginea pasture submitted to different nitrogen levels and forage mass through mathematical models.

\section{Material and Methods}

The work was carried out at the Pato Branco, PR, Brazil, at $26^{\circ} 07^{\prime}$ south and $52^{\circ} 41^{\prime}$ east with an average altitude of $700 \mathrm{~m}$ from November, 2007 up to April 2008. The climate of the region is subtropical humid, according to the Köppen classification (MAAK, 1968), and the soil at the experimental site is classified as an Oxisol (EMBRAPA, 2006).

The establishment of Urochloa plantaginea happened by natural reseeding due to the presence of plants in the area at the prior year. An area of 1.39 ha divided in 12 paddocks which constituted the experimental units, was used. The experimental area was being used under no-tillage system for 10 years with alternate corn and soybeans planting during summer and winter crop in rotation with cereals.

The soil had the following chemical characteristics: $\mathrm{pH}-\mathrm{CaCl}_{2}$ 6.3; $\mathrm{P}: 10.07 \mathrm{mg} \mathrm{kg}^{-1}$; 
$\mathrm{K}: 293.25 \mathrm{mg} \mathrm{kg}^{-1} ; 5.7 \%$ of organic matter; Ca: $8.7 \mathrm{cmol}_{\mathrm{c}} \mathrm{L}^{-1} ; 78 \%$ of base saturation and CEC of $17.49 \%$, and the recommendations to summer grasses, was used $60 \mathrm{~kg} \mathrm{ha}^{-1}$ of $\mathrm{P}_{2} \mathrm{O}_{5}$ using a fertilizer known as triple superphosphate with $41 \%$ of $\mathrm{P}_{2} \mathrm{O}_{5}$ in neutral citrat. According to the soil fertilization handbook, (CQFS, 2004) and the soil chemical analysis, the level of $\mathrm{K}$ in the soil was classified as "too high" and due to it, potassium was not applied through fertilizer at the beginning and during the experimental period.

The experimental design was a random block with treatments in a factorial scheme with two replications. Treatments consisted of a combination of three $\mathrm{N}$ levels $\left(0,200\right.$ and $400 \mathrm{~kg} \mathrm{ha}^{-1}$, using urea) and two forage mass (low mass at $2,000 \mathrm{~kg} \mathrm{ha}^{-1}$ of $\mathrm{DM}$ and high mass in $3,600 \mathrm{~kg} \mathrm{ha}^{-1}$ of DM) in a continuous stocking rate grazing method.

The first evaluation period started on November 11 th and the follow dates 12/13/07, 01/03/08, 01/21/08, 02/12/08, 03/11/08 and 04/01/2008 represents the end of each period.

The nitrogen fertilizations levels were 0, $200 \mathrm{e}$ $400 \mathrm{~kg} \mathrm{ha}^{-1}$ of $\mathrm{N}$ divided into four applications of 50 and $100 \mathrm{~kg}$ of $\mathrm{N} \mathrm{ha}^{-1}$, respectively, to the 200 and $400 \mathrm{~kg} \mathrm{ha}^{-1}$ of $\mathrm{N}$, applied in a topdressing way spreading the nitrogen by hands in intervals of approximately 30 days from the beginning of the experiment always observing the weather conditions and moisture level to get the best use of the $\mathrm{N}$ by the system. The nitrogen source used was urea with a concentration of $45 \%$ of $\mathrm{N}$.

The animals entered the paddocks with a mean forage mass of $3,600 \mathrm{~kg} \mathrm{ha}^{-1}$ of DM, being this value kept to the high forage (HF) mass, and by the stocking rate adjustments, reduced to $2,000 \mathrm{~kg}$ $\mathrm{ha}^{-1}$ of DM to the low forage (LM) mass. Goats half blood Boer with five months of age and average life weight of $21 \mathrm{~kg}$, were used to adjust the wanted forage mass in a continuous stocking rate grazing method, using the put and take method described by Mott and Lucas (1952).
The forage production was assessed by the daily forage accumulation rate ( $\mathrm{kg}$ of $\mathrm{DM} \mathrm{ha}{ }^{-1}$ day $^{-1}$ ) values evaluated on average each 21 days, using two grazing exclusion cage to each experimental unit, using the technique described by Moraes, Moojen and Maraschin (1990).

The forage production of each period was obtained by the multiplying of the dry matter accumulation rate by the days of period. The total forage production was obtained by the initial forage mass plus the forage production of each period. The accumulate forage production in each period was assessed by adding the DM production of first period with the second period and so on successfully until the last period.

The samples of plants, after being collected in the field, were dried in an oven with forced air circulation at $60^{\circ} \mathrm{C}$ until constant weight. After the samples were ground in Willey mill, with a $1 \mathrm{~mm}$ sieve and determined the level of nitrogen $(\mathrm{N})$ by the method suggested by Tedesco et al. (1995).

The relationship between $U$. plantaginea $\mathrm{N}$ uptake and its biomass production was determined according to Lemaire (1997), through the equation for $\mathrm{C} 4$ species: $\mathrm{N}=3.4 \%\left(\mathrm{DM}^{-0.37}\right.$, being $\mathrm{N} \%$, the percentage of nitrogen calculated according to the biomass accumulation; the coefficient 3,4, the percentage of $\mathrm{N}$ present in the plants aerial biomass in a known mass; DM, the amount of dry matter produced by the plant canopy in a pasture and expressed in $\mathrm{t} / \mathrm{ha}$ and the coefficient -0.37 characterizes the nitrogen dilution behavior during the pasture regrowth. Nitrogen critical curve was obtained in the same way, regarding to the amount of nitrogen absorbed by the plants through the equation: Ncritic: $34(\mathrm{DM})^{0.63}$, being the values expressed in $\mathrm{kg} \mathrm{ha}^{-1}$ of $\mathrm{N}$.

The equation for determining the nitrogen nutritional index (NNI) (LEMAIRE; GASTAL; SALETTE, 1989) was: NNI = $(100 * \mathrm{~N} \%) /(3.4$ $\left.* \mathrm{DM}^{-0,37}\right)$. According to it, NNI is classified as: above 100 is considered as excess of nitrogen 
absorption by the plant, levels between 80 and 100 are satisfactory, between 60 and 80 inadequate and below 60 is considered as very poor. The results were submitted to analysis of variance by the test F. When the results showed significance at 5\% probability, the means were compared by Tukey test at $5 \%$ probability of error.

\section{Results and Discussion}

Total dry matter production was significantly higher for treatments with nitrogen $(19,834$ and $17,820 \mathrm{~kg} \mathrm{ha}^{-1}$ of $\mathrm{DM}$, respectively, to the 200 and $400 \mathrm{~kg} \mathrm{ha}^{-1}$ of $\mathrm{N}$ ) when compared with the treatment without nitrogen $\left(13,659 \mathrm{~kg} \mathrm{ha}^{-1}\right.$ of DM). Some studies also show the same effect of the nitrogen (MARTINS; RESTLE; BARRETO, 2000; LANÇANOVA; RESTLE; SANTOS, 1988; AITA, 1995).

To study the dilution curve proposed by Lemaire (1997) and the pasture nutritional index, it was required to monitor the dry matter accumulated during the evaluation period. Forage yield was similar among the experimental periods (average of $2,850 \mathrm{~kg} \mathrm{ha}^{-1}$ of DM) with a grazing period of 107 days. U. plantaginea showed a good forage production throughout the growing season with a productive cycle relatively long when compared with other species such as millet and sorghum (RESTLE et al., 2002) showing to be a good alternative to the animal production.

The $\mathrm{N}$ concentration was not affected by the forage mass, but it was observed a slight tendency of higher $\mathrm{N}$ concentration $\left(20 \mathrm{~g} \mathrm{~kg}^{-1}\right)$ at the low mass when with high mass $\left(19,4 \mathrm{~g} \mathrm{~kg}^{-1}\right)$. Comparing two forage mass in a similar forage receiving similar fertility and climate conditions, the one managed at a higher mass tends to have more nitrogen dissolved in its biomass and due to it, nitrogen content tends to be lower when compared with lower forage mass, where nitrogen is more concentrated, and therefore in higher levels in the plant (LEMAIRE, 1997).
On the other hand, pasture biomass nitrogen content was significantly affected by the addition of nitrogen fertilizers. The percentages of $\mathrm{N}$ in the shoots of the $U$. plantaginea were 14.9, 21.1 and $23 \mathrm{~g} \mathrm{~kg}^{-1}$ of DM for 0,200 and $400 \mathrm{~kg} \mathrm{ha}^{-1}$ of $\mathrm{N}$, respectively. The addition of 200 and $400 \mathrm{~kg}$ $\mathrm{ha}^{-1}$ of $\mathrm{N}$ increased the $\mathrm{N}$ content in $29.4 \%$ and $35.2 \%$ respectively, in the $U$. plantaginea pasture, values which were significantly higher than those observed in the plants that did not receive nitrogen fertilization. Although there were no significant differences between 200 and $400 \mathrm{~kg} \mathrm{ha}^{-1}$ of $\mathrm{N}$, the percentage of the element in the pasture tends to increase. It is expected an increase in the plant nitrogen levels as the high nitrogen availability in the soil for a large number of forage species tested, including $U$. plantaginea as shown by Lançanova, Restle and Santos (1988), Martins, Restle and Barreto (2000) and Aita (1995). Furthermore, according to Malavolta (1987), appropriate nitrogen concentration for Urochloa spp would be of $17 \mathrm{~g}$ $\mathrm{kg}^{-1}$ of DM.

Based on the comparisons done with the percentage of $\mathrm{N}$ found in the $U$. plantaginea shoots and the accumulated DM production in relation to the $\mathrm{N}$ application levels and forage mass it is possible to observe (Figure 1) at the treatment without $\mathrm{N}$ application that the element concentration in the plant remained almost in all the cycle, below the critical curve proposed by Lemaire (1997) indicating inadequate supply and $\mathrm{N}$ uptake by the plants in this treatment. With little less than $5 \mathrm{t} \mathrm{ha}^{-1}$ of herbage accumulation (51 days after emergence) the level of $200 \mathrm{~kg} \mathrm{ha}^{-1}$ of $\mathrm{N}$ was also limiting the plant. This is explained by the fact that this treatment received the smallest fraction $(50 \mathrm{~kg}$ $\mathrm{ha}^{-1}$ of $\mathrm{N}$ ) of total added urea when compared with the plots that received $400 \mathrm{~kg} \mathrm{~N} \mathrm{ha}^{-1}\left(100 \mathrm{~kg} \mathrm{ha}^{-1}\right.$ of $\mathrm{N})$, considering that the $\mathrm{N}$ application was splitted in four applications. 
Figure 1. Nitrogen dilution curve (Figure 1A) proposed by Lemaire (1997) related to the absorbed nitrogen (Figure 1B) according to Urochloa plantaginea biomass accumulation in relation to three nitrogen level and two grazing intensities.

(A)

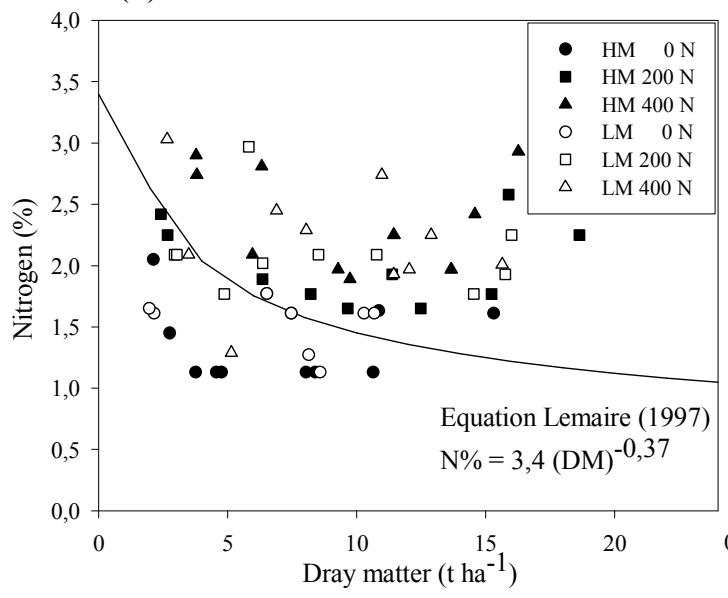

(B)

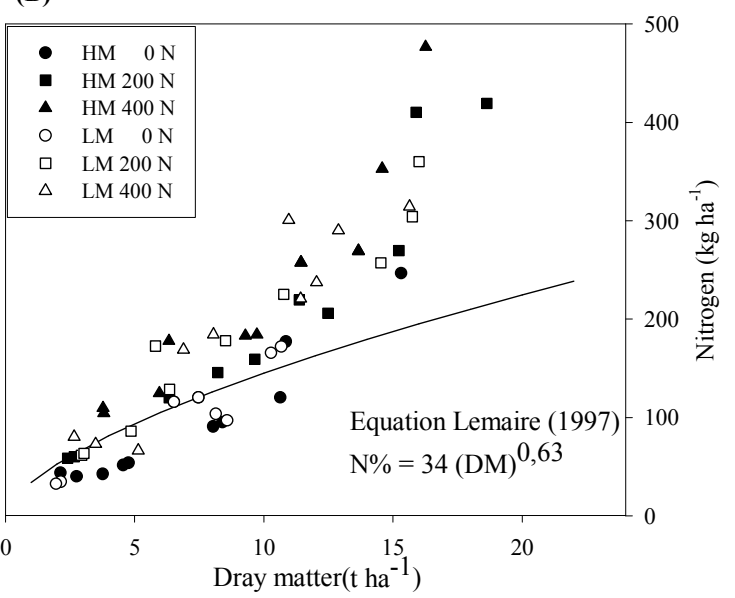

Source: Elaboration of the authors.

After successive nitrogen applications, pasture started to show satisfactory nitrogen nutritional indices and according to the plant biomass analysis, there was a nitrogen "luxury" consumption, that is in other words, consumption beyond what would be necessary for its growth, which may characterize the highest forage quality or accumulation of reserves (LEMAIRE; GASTAL; SALETTE, 1989). These results allow to prove the effectiveness of the method in checking the nutritional status of the pasture.

According to the results found in this work, first nitrogen application should be higher when it is applied in parts, because doing so, the plants would be supplied with $\mathrm{N}$ requirement from the beginning of cultivation.

In order to determine whether the plant was being adequately nourished in relation to the nitrogen fertilization, was studied the nitrogen nutrition index (NNI). As proposed by Lemaire, Gastal and Salette (1989), the concept of critical nitrogen concentration can be defined as the lowest concentration of $\mathrm{N}$ required to allow maximum crop growth rate at a certain stage of its growth (PLÉNET; LEMAIRE, 2000).

As Figure 2A shows, plants that had not received $\mathrm{N}$ fertilization showed nutritional indices classified as insufficient until reach an accumulated dry matter near $9,000 \mathrm{~kg} \mathrm{ha}^{-1}(02 / 12 / 08)$, just in the last two assessment periods, these plants start to show sufficiency nitrogen levels. Sartor (2009) concluded that there was a P limitation in the last growing season which resulted in lower DM accumulation and, therefore, resulted in $\mathrm{N}$ concentration in plant tissue. 
Figure 2. Nitrogen nutrition index (Figure 2A) and accumulated nitrogen absorbed amount (Figure 2B) of a Urochloa plantaginea pasture in relation to nitrogen levels and dry matter accumulated.
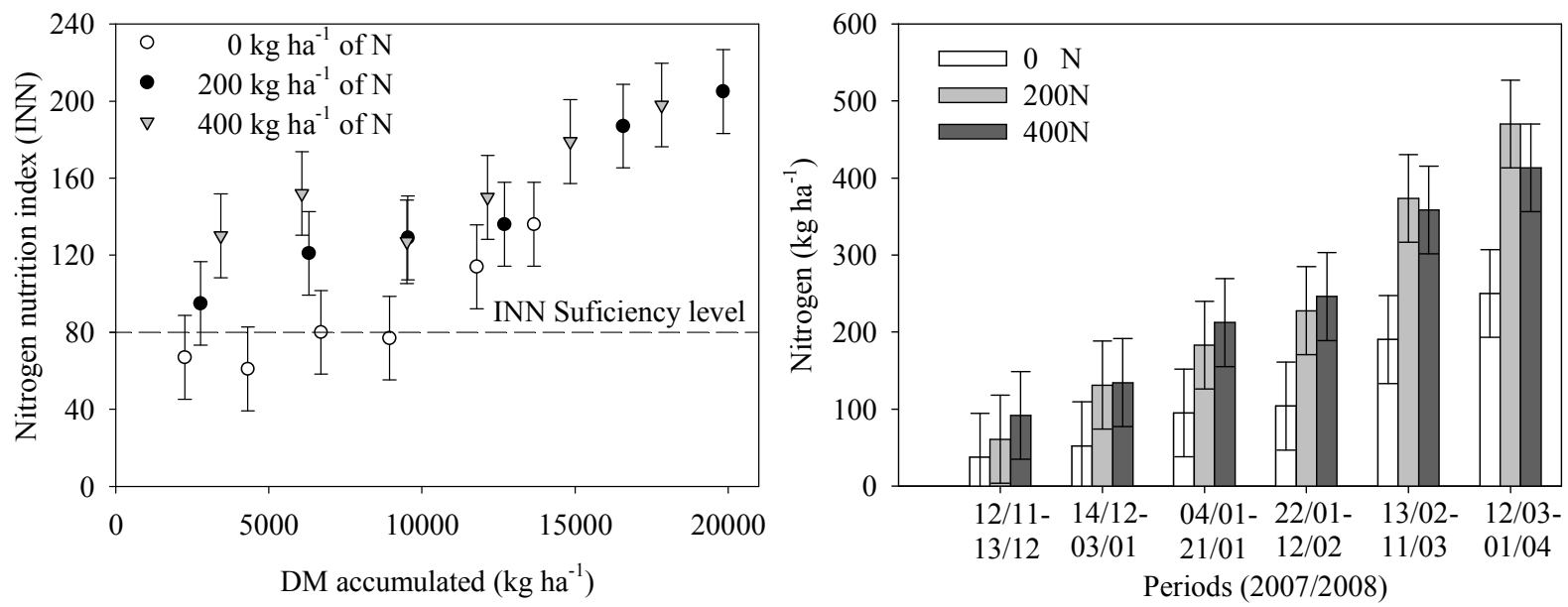

Bars that are not coincident the averages differ between the treatments by the Tukey test at 5\% probability of error. Source: Elaboration of the authors.

This behavior is linked to the amount of available $\mathrm{N}$ between the treatments and, according to the assumptions of Lemaire, Gastal and Salette (1989), as the $\mathrm{N}$ availability for the plant increases, higher is the concentration of $\mathrm{N}$ in their tissues due to accumulation of reserves coming from fertilizer, not using for growth and biomass production.

Nitrogen fertilizer application may have also contributed to accelerating the process of organic matter decomposition and nutrients release to the plant, increasing its availability in the fertilized plots. Another important factor is the animal influence over the nutrient cycling, once nutrients such as $\mathrm{N}$ present in the urine and feces might be faster available than the nutrients present in the plants litter (BAUER; COLE; BLACK, 1987).

As the $U$. plantaginea dry matter production increased, the amount of $\mathrm{N}$ absorbed by the plant (Figure 1 and Figure 2B) also increased. Similar results were reported by Bortolini, Silva and Argenta, (2000) and Bobato (2006) in maize crop cultivation.

To Bobato (2006), the limiting threshold between sufficiency and deficiency of $\mathrm{N}$ in maize occurs at the $\mathrm{N}$ level of $120 \mathrm{~kg} \mathrm{ha}^{-1}$ of $\mathrm{N}$, while for 0 and 60 $\mathrm{kg} \mathrm{ha}^{-1}$ of $\mathrm{N}$ was obtained amounts of $\mathrm{N}$ absorbed by the culture below the critical level. Also Herrmann and Taube (2004) evaluating 0, 50 and $150 \mathrm{~kg} \mathrm{ha}^{-1}$ of $\mathrm{N}$ in maize observed inadequate levels of $\mathrm{N}$ for 0 and $50 \mathrm{~kg} \mathrm{ha}^{-1}$ of $\mathrm{N}$ and suitable for the highest level.

Along all the experimental periods, plant nitrogen uptake in relation to the $\mathrm{N}$ fertilization resulted in values of 470 and $413 \mathrm{~kg} \mathrm{ha}^{-1}$ of N (Figure 2B) to the application of 200 and $400 \mathrm{~kg} \mathrm{ha}^{-1}$ of N, respectively, with accumulated forage production of 19,834 and $17,820 \mathrm{~kg} \mathrm{ha}^{-1}$ of DM. Without nitrogen application, plant accumulated $250 \mathrm{~kg} \mathrm{ha}^{-1}$ of $\mathrm{N}$. Nitrogen uptake by the plants that received nitrogen fertilization was significantly higher than the plants at the treatment without nitrogen, since January $22^{\text {nd }}$.

It is observed that at no time the amounts of $\mathrm{N}$ absorbed differed statistically between the 200 and $400 \mathrm{~kg} \mathrm{ha}^{-1}$ of $\mathrm{N}$, regardless the fact that at the initial growth phase, the $\mathrm{N}$ splitting at the $200 \mathrm{~kg} \mathrm{ha}^{-1}$ of $\mathrm{N}$ has caused it to present points below the critical dilution curve proposed by Lemaire (1997) (Figure 1), thereby demonstrating the U. plantaginea nitrogen recovery potential and possibly if a greater portion of $\mathrm{N}$ was applied at the initial stage of development, probably $200 \mathrm{~kg} \mathrm{ha}^{-1}$ of $\mathrm{N}$ could be an appropriate level for the cultivation of this Urochloa. 
According to Lançanova, Restle and Santos (1988), Urochloa plantaginea has high rates of forage production of good quality if properly managed and fertilized. This high productivity and quality of $U$. plantaginea are unknown and undervalued by farmers, as it is usually desiccated for further cultivation of other forages such as millet, sorghum or even other Urochloa spp.

According to literature data (LANÇANOVA; RESTLE; SANTOS, 1988; AITA, 1995; MARTINS; RESTLE; BARRETO, 2000) and from this results found in this work, it is possible to infer that there is a large financial and environmental loss to the agricultural properties when this species is desiccated in order to sow another one. It is important to consider this species as a foraging option, although it is considered a weed plant and seed trade is not yet possible. It should also be noted that research has been conducted to assess the $U$. plantaginea as a plant controller of other weeds in the crop livestock system (FREITAS et al., 2005; GIMENES, 2007).

\section{Conclusion}

Lack of nitrogen application showed by the unsatisfactory nitrogen nutritional index limits. $U$. plantaginea growth, fact that was not observed at the $400 \mathrm{~kg} \mathrm{ha}^{-1}$ of $\mathrm{N}$ where nitrogen "luxury" consumption occurred showed by the satisfactory levels of this nutrient in the plant tissue. $U$. plantaginea showed to be excellent forage specie due to its high productivity, long-term use and high nutritional value being the nitrogen index a useful tool for plant nutritional status diagnosis during its cultivation.

\section{References}

AITA, V. Utilização de diferentes pastagens de estação quente na recria de bovinos de corte. 1995. Dissertação (Mestrado em Zootecnia) - Curso de Pós-graduação em Zootecnia. Universidade Federal de Santa Maria, Santa Maria.
ARAÚJO, A. A. Forrageiras para ceifa. Porto Alegre: Ed. Sulina, 1967. 257 p.

BAUER, A.; COLE, C. V.; BLACK, A. L. Soil property comparisons in virgin grassland between grazed and nongrazed management systems. Journal Soil Science Society of America, Florida, v. 51, n. 3, p. 176-182, 1987.

BOBATO, A. Índice nutricional do nitrogênio: uma ferramenta para o diagnóstico do estado nutricional da cultura do milho. 2006. Dissertação (Mestrado em Agronomia) - Pós-Graduação em Ciência do Solo. Departamento de Solos e Engenharia Agrícola. Setor de Ciências Agrárias. Universidade Federal do Paraná, Curitiba.

BORTOLINI, C. G.; SILVA, P. R. F.; ARGENTA, G. Sistemas consorciados de aveia preta e ervilhaca comum como cobertura de solo e seus efeitos na cultura do milho em sucessão. Revista Brasileira de Ciência do Solo, Santa Maria, v. 24, n. 2, p. 897-903, 2000.

COLNENNE, C.; MEYNARD, J. M.; REAU, R.; JUSTES, E.; MERRIEN, A. Determination of a critical nitrogen dilution curve for winter oilseed rape. Annals of Botany, Oxford, v. 81, n. 3, p. 311-317, 1998.

COMISSÃO DE QUÍMICA E FERTILIDADE DO SOLO - CQFS. Manual de adubação e calagem para os Estados do Rio Grande do Sul e de Santa Catarina. 10. ed. Porto Alegre: SBCS-Núcleo Regional Sul/UFRGS, 2004. $400 \mathrm{p}$.

DURU, M.; LEMAIRE, G.; CRUZ. P. The nitrogen requirements of major agricultural crops: grasslands. In: LEMAIRE, G. (Ed.). Diagnosis on the nitrogen status in crops. Heidelberg: Springer-Verlag, 1997. p. 59-72.

EMPRESA BRASILEIRA DE PESQUISA AGROPECUÁRIA - EMBRAPA. Sistema Brasileiro de Classificação de Solos. 2. ed. Rio de Janeiro, Embrapa Solos, 2006. 306 p.

FREITAS, F. C. L.; FERREIRA, L. R.; FERREIRA, F. A.; SANTOS, M. V.; AGNES, E. L.; CARDOSO, A. A.; JAKELAITS, A. Formação de pastagem via consórcio de Brachiaria brizantha com milho para silagem no sistema de plantio direto. Revista Planta Daninha, Viçosa, v. 23, n. 1, p. 49-58, 2005.

GIMENES, M. J. Alternativa de consórcio entre milho e brachiárias no manejo e controle de plantas daninhas. 2007. Dissertação (Mestrado em Fitotecnia) - Universidade de São Paulo, Escola Superior de Agricultura Luiz de Queiroz, Piracicaba.

HERRMANN, A.; TAUBE, F. The range of the critical nitrogen dilution curve for maize (Zea mays L.) can be extended until silage maturity. Agronomy Journal, Madison, v. 96, n. 4, p. 1131-1138, 2004. 
JARVIS, S. C. Soil-plant-animal interactions and impact on nitrogen and phosphorus cycling and re-cycling in grazed pastures. In: SIMPÓSIO INTERNACIONAL GRASSLAND ECOPHYSIOLOGY AND GRAZING ECOLOGY, 1., 1999, Curitiba. Proceedinds... Curitiba: Ed. UFPR, 1999. p. 215-234.

LANÇANOVA, J. A. C.; RESTlE, J.; SANTOS, G. L. Produção e qualidade do capim papuã (Brachiaria plantaginea) sob efeito de frequências de corte e nitrogênio. Ciência Rural, Santa Maria, v. 18, n. 5 p. 343354, 1988.

LEMAIRE, G. (Ed.). Diagnosis of the nitrogen status in crops. Berlin: Springer, 1997. 56 p.

LEMAIRE, G.; GASTAL, F. N uptake and distribution in plant canopies. In: LEMAIRE, G. (Ed.). Diagnosis on the nitrogen status in crops. Heidelberg: Springer-Verlag, 1997. p. 3-43.

LEMAIRE, G.; GASTAL, F.; SALETTE, J. Analysis of the effect of $\mathrm{N}$ nutrition on ry matter yield of a swad by reference to potencial yield and optimum $\mathrm{N}$ content. In: INTERNATIONAL GRASSLAND CONGRESS, 16., 1989, Nice. Proceedinds... Nice: Ed. Association Francaise pour la Production Fourragere, 1989. p. 179180.

LEMAIRE, G.; JEUFFROY, M. H.; GASTAL, F. Diagnosis tool for plant and crop $\mathrm{N}$ status in vegetative stage, Theory and practice for crop $\mathrm{N}$ management. European Journal of Agronomy, Taastrup, v. 28, n. 4, p. 614-624, 2008.

LEMAIRE, G.; SALETTE, J. Relation entre dynamique de croissance et dinamique de prévèlement d'azote pour un peuplement de graminées fourragères. I. Etude de l'effet du milieu. Agronomie, Paris, v. 4, n. 4, p. 423-430, 1984.

MAAK, R. Geografia fisica do estado do Paraná. Curitiba: Banco de Desenvolvimento do Paraná, 1968. $350 \mathrm{p}$.

MALAVOLTA, E. Manual de calagem e adubação das principais culturas. Ceres, São Paulo, 1987. 496 p.

MARTINS, J. D.; RESTLE, J.; BARRETO, I. L. Produção animal em capim papuã (Brachiaria plantaginea (Link) Hitchc) submetido a níveis de nitrogênio. Ciência Rural, Santa Maria, v. 30, n. 5, p. 887-892, 2000.

MORAES, A.; MOOJEN, E. L.; MARASCHIN, G. E. Comparação de métodos de estimativa de taxas de crescimento em uma pastagem submetida a diferentes pressões de pastejo. In: REUNIÃO ANUAL DA SOCIEDADE BRASILEIRA DE ZOOTECNIA, 27., 1990, Campinas. Anais... Campinas: SBZ, 1990. 332 p.
MOTT, G. E.; LUCAS, H. L. The design, conduct en interpretation of grazing trials on cultivated and improved pastures. In: INTL GRASSLD CONGRESS, 6., 1952, Pennsilvania. Proceeding... Washington: Ed. State College Press, 1952. p. 1380-1385.

NEY, B.; DORE, T.; SAGAN, M. The nitrogen requirement of major agricultural crops: grains legumes. In: LEMAIRE, G. (Ed.). Diagnosis on the nitrogen status in crops. Heidelberg: Springer-Verlag, 1997. p. 107-117.

PLÉNET, D.; CRUZ, P. The nitrogen requirement of major agricultural crops: maize and sorghum. In: LEMAIRE, G. (Ed.). Diagnosis on the nitrogen status in crops. Heidelberg: Springer-Verlag, 1997. p. 93-106.

PLÉNET, D.; LEMAIRE, G. Relationships between dynamics of nitrogen uptake and dry matter accumulation in maize crops. Plant Soil, New York, v. 216, n. 1, p. 65$82,2000$.

RESTLE, J.; ROSO, C.; AITA, V.; NORNBERG, J. L.; BRODANI, I. L.; CERTÓDES, L.; CARRILHO, C. O. Produção animal em pastagem com gramíneas de estação quente. Revista Brasileira de Zootecnia, Viçosa, v. 31, n. 3, p. 1491-1500, 2002.

SARTOR, L. R. Eficiência de utilização de nitrogênio, fósforo e potássio por plantas de papuã submetidas a diferentes intensidades de pastejo e niveis de nitrogênio. 2009. Dissertação (Mestrado em Agronomia) Universidade Tecnológica Federal do Paraná, Pato Branco.

SHEEHY, J. E.; DIONORA, M. J. A.; MITCHELL, P. L.; PENG, S.; CASSMAN, K. G.; LEMAIRE, G.; WILLIAMS, R. L. Critical concentrations: implications for highyielding rice (Oryza sativa L.) cultivars in tropics. Field Crops Research, Nottingham, v. 59, n. 1, p. 31-41, 1998.

SILVA, S. C.; NASCIMENTO JUNIOR, D. Sistema intensivo de produção de pastagens In: CONGRESSO LATINO-AMERICANO DE NUTRIÇÃO ANIMAL, 2., 2006, São Paulo. Anais... São Paulo: CBNA, 2006. CDROM.

TEDESCO, M. J.; GIANELLO, C.; BISSANI, C. A.; BOHNEN, H.; VOLKWEISS, S. J. Análise de solo, plantas e outros materiais. Porto Alegre: UFRGS, 1995. $174 \mathrm{p}$. 